УДК 502.51(477)

DOI 10.47049/2226-1893-2021-2-152-158

\title{
ПРЯМІ ТА НЕПРЯМІ АНТРОПОГЕННІ НАВАНТАЖЕННЯ НА ВОДНІ РЕСУРСИ УКРАЇНИ
}

\author{
К.Ю. Федорова \\ к.т.н, доцент кафедри \\ «Цивільна інженерія та архітектура» \\ Н.Н. Хонелія \\ к.т.н, доцент кафедри \\ Одеський національний морський університет, Одеса, Украӥна
}

«Морські і річкові порти, водні шляхи та їх технічна експлуатація»

Анотація. Стан навколишнього середовища в Україні характеризується високим рівнем антропогенного навантаження. Людина в результаті своєї діяльності завдавала и продовжує завдавати великої шкоди навколишньому середовищу.

Антропогенне навантаження на навколишнє середовище- це величина прямого або непрямого впливу людини та його господарської діяльності. Антропогенне навантаження відображає кількість негативного виливу на природу. Антропогенне навантаження змінює характер екологічної рівноваги. Вивчаючи характер антропогенного навантаження людина може корегувати цеей негативний вплив.

Такі питання необхідно постійно моніторити, вивчати, аналізувати їх кількісний та якісний склад, виробляти дієві методи боротьби з антропогенними навантаженнями, що допоможе зберегти на довгі роки надбання українського народу - водні ресурси Украӥни.

Ключові слова: антропогенні навантаження, прямий вплив, непрямий вплив, негативний вплив, поверхневі джерела, підземні джерела.

УДК 502.51(477)

DOI 10.47049/2226-1893-2021-2-152-158

ПРЯМЫЕ И КОСВЕННЫЕ АНТРОПОГЕННЫЕ НАГРУЗКИ НА ВОДНЫЕ РЕСУРСЫ УКРАИНЫ

\author{
Е.Ю. Федорова \\ к.т.н., доцент кафедры \\ «Гражданская инженерия и архитектура» \\ Н.Н. Хонелия \\ к.т.н., доцент кафедры \\ Одесский национальный морской университет, Одесса, Украина
}

«Морские и речные порты, водные пути и их техническая эксплуатация»

() Федорова К.Ю., Хонелія Н.Н., 2021 
Аннотация. Состояние окружающей среды в Украине характеризуется высоким уровнем антропогенной нагрузки. Человек в результате своей хозяйственной деятельности наносил и продолжает наносить большой ущзерб окружающей среде.

Антропогенная нагрузка на окружаюшую среду- это величина прямого или косвенного воздействия человека и его хозяйственной деятельности. Антропогенная нагрузка отражает количество негативного воздействия на природу. Антропогенная нагрузка меняет характер экологического равновесия. Изучая характер антропогенной нагрузки, человек может корректировать это негативное влияние.

Такие вопросы необходимо постоянно мониторить, изучать, анализировать их количественный и качественный состав, вырабатывать действенные методы борьбы с антропогенными нагрузками, что поможет сохранить на долгие годы достояние украинского народа - водные ресурсы Украины.

Ключевые слова: антропогенная нагрузка, прямое воздействие, косвенное воздействие, негативное воздействие, поверхностные источники, подземные источники.

UDC 502.51(477)

DOI 10.47049/2226-1893-2021-2-152-158

\section{PRACTICE OF APPLICATION OF DYNAMIC GEOMETRY GEOGEBRA IN UNIVERSITIES IN TEACHING CONSTRUCTION DISCIPLINES}

Catherine Fedorova

$\mathrm{PhD}$, docent of the department «Civil Engineering and Architecture» Natela Khonelia

$\mathrm{PhD}$, docent of the department «Marine and river ports, waterways and its technical service» Odessa National Maritime University, Odessa, Ukraine

Abstract. The state of the environment in Ukraine is characterized by a high level of anthropogenic pressure. As a result of his economic activities, man has caused and continues to cause great damage to the environment.

Anthropogenic load on the environment is the magnitude of the direct or indirect impact of humans and their economic activities. Anthropogenic load reflects the amount of negative impact on nature. Anthropogenic load changes the nature of the ecological balance. By studying the nature of the anthropogenic load, a person can correct this negative influence.

Such issues need to be constantly monitored, studied, analyzed in quantitative and qualitative composition, to develop effective methods of combating anthropogenic loads, which will help preserve the heritage of the Ukrainian people for many years - the water resources of Ukraine.

Keywords. Anthropogenic load, direct impact, indirect impact, negative impact, surface sources, underground sources. 
Введення. Забруднення води та повітря останнім часом тільки збільшується за рахунок збільшення кількості промислових об'єктів, великих мегаполісів із великою кількістю людей, навіть зростання чисельності автомобілей є проблемою.

За останні 40-50 років людство своєю діяльністю прямо чи опосередковано знищує таку кількість цінних видів тварин, птахів, риб, рослин, що вчені порівнюють цей процес із глобальним вимиранням, яке відбувалося більше мільйона років тому.

Вода і повітря - основні елементи, без одного з яких людство не може існувати. Звичайно, розробляти методики очищення куди складніше, ніж стежити за забрудненням повітря та води.

Звернемося до проблем збереження чистої питної води. Які труднощі зустрічаються на шляху дослідників, як їх можна подолати, як збільшити перевірку забруднення водних ресурсів, які показники особливо важливі. Ці питання ми розглянемо в статті.

Останніми роками питання, що пов'язані з питним водопостачанням, набувають надзвичайної актуальності не тільки в Україні, але й в усіх країнах світу. Дійсно, споживання неякісної питної води часом викликає серйозні проблеми із здоров'ям людини, яка споживає цю воду. Якість води більшої частини поверхневих джерел водопостачання дуже часто не відповідає нормативним вимогам.

Постановка проблеми. На території великих міст України виникають основні проблеми водного господарства. Концентрація у містах населення та значного промислового потенціалу перетворюються у потужні джерела забруднення водних об‘єктів стічними водами. Сюди відносяться комунальні, промислові, зливові, дренажні стічні води, які формують так звані міські стічні води.

У багатьох країнах Африки, Азії, Південної Америки забруднення питної води стає потенційною небезпекою.Зростають епідеміологічні загрози. Постійно спостерігаються спалахи захворювань, однак вирішити проблему у цих регіонах практично неможливо.

Ось чому потрібно негайно вирішувати питання забруднення питних джерел води у нас в Україні. Необхідно вважати ці завдання першочерговими і важливими. Потрібно проводити регулярні дослідження водойм для виявлення ступеня забруднення.

Екологічне забруднення набуває глобального характеру. Скрізь у всіх країнах світу відбувається скорочення питних джерел.

Промислові підприємства неодноразово скидають значну кількість хімікатів в озера і річки, які вважаються джерелами питної води в населених пунктах.

Не можна залишати без уваги наступну екологічну проблему - забруднення підземних водойм. До речі, підземні водойми $є$ одним з голов- 
них джерел води, які поступово виводять 3 придатної для вживання у зв'язку з дедалі більшим забрудненням.

Постановка задачі. Основною причиною неблагополучного стану поверхневих водних ресурсів $є$ постійне зростання антропогенних навантажень. Для того, щоб поліпшити стан поверхневих водних ресурсів, треба розуміти механізм походження цих антропогенних навантажень, що, в свою чергу, дасть можливість науковій спільноті зменшити їх.

Звісно, при цьому зростає роль підземних вод у централізованому водопостачанні. Проте підземні води є лише малою частиною в потребі питної води при постійно зростаючій чисельності людей на планеті.

Необхідно розібратися 3 причиною зростання антропогенних навантажень, виробити методику очищення поверхневих та підземних водойм, вирішити задачі запобігання забрудненню з урахуванням сучасних світових розробок у цьому напрямку. Особливу роль повинні відігравати контролюючі організації, які допоможуть зменшити антропогенні навантаження при постійному іï моніторингу.

Основний матеріал дослідження. Основними джерелами водопостачання в більшості регіонів планети залишаються поверхневі водойми, забруднення яких постійно зростає.

Антропогенний вплив на природу в буквальному сенсі породжений людиною. Це - вплив людини на біосферу. Цим антропогенний вплив відрізняється від природних факторів, які виникли ще до появи людини. Але, на жаль, і природні фактори впливу на біосферу діють до сих пір. Слід відмітити, що вплив людини як екологічного фактора дуже високий. Ніяка екосистема світу не уникла цього впливу.

Сьогодні світ техніки практично перетворився на самостійну реальність. Природа повністю підпорядкована людині. Через це існує необхідність охорони навколишнього середовища регіонального, локального та державного рівнів.

Антропогенні навантаження на водні ресурси збільшуються у зв'язку з господарчою діяльністю підприємств промисловості, сільського господарства та житлово-комунального комплексу.

Антропогенні навантаження на водні об‘єкти від точкових джерел забруднення постійно збільшуються. Це обумовлено перш за все процесами урбанізації, коли основна частина населення планети зосереджена в містах. У зв'язку з цим тут зосереджене основне економічне життя, що призводить до збільшення навантаження на водні об‘єкти. Більшість промислових підприємств використовують воду, яка в результаті виявляється дуже брудною.

Антропогенні навантаження поділять на непрямі та прямі.

Якщо антропогенні навантаження змінюють просторову структуру або фізичні та хімічні властивості геосистем водяних об“єктів, їх відно- 
сять до непрямого впливу. Це агротехнічні, меліоративні заходи, внесення різних добрив тощо.

В ролі показників непрямих антропогенних навантажень розглядається просторово-часова динаміка зміни площі сільськогосподарських культур, врожайності зернових культур, обсягів внесення мінеральних і органічних добрив.

Непрямі антропогенні навантаження поділяються на декілька груп:

- органолептичні - смак, запах, каламутності і т. д.;

- хімічні - хлориди, нітрати, сульфати.

Фекальні забруднення відрізняються не тільки наявністю групи кишкових паличок, але й збільшенням кількості азоту, нітратів і хлоридів.

Найнебезпечнішим вважається свіже забруднення.

Особливу увагу треба приділяти азотовмісним забрудненням та забрудненням рослинного походження, тобто добривам в тій чи іншій формі.

Що стосується прямих факторів антропогенних впливів, то це нетривала діяльність людини, яка здатна вплинути на природу. Сюди відносяться некомпетентна вирубка лісів, висушування річок і озер, затоплення окремих ділянок землі заради будування ГЕС та ін.

До прямих антропогенних навантажень відносяться:

- бактеріологічні - загальне мікробне число патогенних ентеробактерій та кількість загальних колі-форм;

- паразитологічні - клітини, яйця, личинки, кишкові паразити.

Забруднення водних об'єктів характеризується рядом показників. В основу обирають пріоритетні забруднюючі речовини, особливо ті, які мають властивості накопичення в органах і тканинах гідробіонтів.

Ступінь забруднення поверхневих вод базується на 4 класах показників, які в більшості є нормативними.

Але насторожує той факт, що в основному користуються показниками I та II груп або класів, а III та IV групи вважають додатковими. Вони нібито використовуються для підтвердження інтенсивного антропогенного забруднення вододжерела при визначенні точних показників.

Цей факт не тішить. Контролюючим органам слід звернути увагу, що всі антропогенні забруднення шкідливі для людини.

Для промислових показників особливо шкідлива концентрація водневих іонів. Величина $\mathrm{pH}$ забезпечує найбільш достовірну інформацію про рівень забруднення водоймища промисловими відходами. Необхідно підтримувати концентрацію водневих іонів на оптимальному рівні. Цей показник необхідно моніторити постійно в стічних водах виробництва.

Дуже перспективними в цьому випадку $є$ ефективні науковообгрунтовані методи використання вод, охорони водних ресурсів від забруднення та знищення. Основною науковою задачею подальших 
досліджень $є$ розробка методики та оцінка гідрологічних наслідків просторово-часових спільних змін прямих та непрямих антропогенних навантажень на річковий стік, інші елементи водного балансу та якість води водних ресурсів.

В цілому сучасний стан водних ресурсів України можна оцінювати як вельми несприятливий. Певні перспективи його поліпшення пов'язані з Водним кодексом України, куди постійно вносяться зміни відповідно до законів, прийнятих Верховною Радою. Останні зміни ввели в дію Постановою ВР №1423-IX від 28.04.2021 р. Згідно з цими постановами всі водні об‘єкти на території України є національним надбанням українського народу, однією 3 природніх основ його економічного та соціального добробуту.

В умовах зростання антропогенних навантажень на природне середовище виникає необхідність розробки та підтримання особливих правил раціонального використання водних ресурсів i ïx екологічно направленого захисту.

Для цього пропонується використовувати весь комплекс організаційних, правових та виховних заходів, які будуть сприяти формуванню водно-екологічного правопорядку.

Висновки. Оцінка величин антропогенного навантаження та аналіз її просторово-часової мінливості на території України є необхідними елементами при організації моніторингу та регулювання негативної дії на якість водотоків. Без детального вивчення навантажень неможливо виявити зв 'язки між кількістю скидаємих забруднюючих речовин у складі стічних вод і концентраціями хімічних речовин у воді водойм.

Оцінка антропогенного навантаження необхідна при нормуванні впливу точкових джерел забруднення, в тому числі при розрахунках гранично допустимого скидання речовин (ГДС), які надходять зі стічними водами у водні об'єкти, та гранично допустимого шкідливого впливу (ГДШВ) на водні об‘ єкти.

Необхідно виконувати всі вимоги профілактики захворювань водного походження:

1. Раціонально здійснювати вибір джерела водопостачання для населених пунктів;

2. Організувати зону санітарної охорони цього водного джерела з регулярним моніторингом якості води;

3. Стандартизувати якість води та всіх нормативних коефіцієнтів і звести ці показники в єдине ціле. Вважати всі нормативні показники обов'язковими та важливими без поділу на класи;

4. Проводити ефективне знезараження води з урахуванням усіх світових досягнень;

5. Використовувати як джерела водопостачання тільки міжпластові води із залягаючими між пластами водостійкими породами. 
Виконувати всі заходи 3 охорони водних ресурсів. Це набагато дешевше і продуктивніше, ніж зіткнуться 3 проблемами нестачі чистої питної води.

\section{ЛIТЕРАТУРА}

1. Новицька Н.В. Анализ факторов антропогенной нагрузки на окружаюшую природную среду. К.: ЛОГОС. 2012. С. 383-394.

2. Водний Кодекс Украйни від 6 червня 1995 року № 213/95-ВР (із змінами та доповненнями станом на 24.07.2021 р.).

3. Рибалова О.В., Белан С.В., Варивода С.О. Визначення рівня екологічної небезпеки в регіонах Украӥни на основі оцінки екологічного ризику // Збірка наукових праџь. 2010. № 12. C. $132-142$.

4. Стойко С.М., Койнова І.Б. Сучасні види антропогенного впливу на життєве середовище // Украйнський географічний журнал. 2012. № 1 .

\section{REFERENCES}

1. Novitska, N.V. Analiz factorov antropogennoi nagryzki na okryzhayzhyiu prirodnyiu seedy. K.: LOGOS. 2012. S. 383-394.

2. Vodniy Kodeks Ykraini vid 6 chervnya 1995 riky № 213/95-VR (iz zminami ta dopivnennyami stanom na 24.07.2021 r.).

3. Rubalova, O.V., Belan S.V., Varuvoda E.O. Viznachennya rivnya ekologivhnoi nebezpekiv regional Ykraini na osnoviozinki ekologichnogo riziky // Zbirka naykovix praz. 2010. №12. S. 132142.

4. Stoiko, S.M., Koinova, I.B. Sychasni vidi antropogennogo vplivyna zhitteve seredovuzhe. Ykrainskiy geographichniy zhyrnal. 2012. № 1 .

Стаття надійшла до редакиії 18.02 .2021

Посилання на статтю: Федорова К.Ю., Хонелія Н.Н. Прямі та непрямі антропогенні навантаження на водні ресурси України // Вісник Одеського національного морського університету: Зб. наук. праць, 2021. № 2(65). C. 152-158. DOI 10.47049/2226-1893-2021-2-152-158.

Article received 18.02.2021

Reference a JournalArtic: Fedorova C., Khonelia N. Practice of Application of Dynamic Geometry Geogebra sn universities in teaching construction disciplines // Herald of the Odessa national maritime university. 2021. № 2(65). C. 152-158. DOI 10.47049/2226-1893-2021-2-152-158. 